\title{
The Role of Intrapreneurship in Portuguese Startups
}

\author{
Fernando Almeida1*, Jorge Miguel-Oliveira² \\ ${ }^{1}$ Department of Computer Science, Faculty of Engineering, University of Porto \& INESC TEC, Dr. Roberto Frias street, \\ 4200-465 Porto, Portugal \\ 2 School of Business Sciences, Polytechnic Institute of Gaya, Av. dos Descobrimentos 333, 4400-103 Villa Nova de Gaia, Portugal \\ * Corresponding author, e-mail: almd@fe.up.pt
}

Received: 03 January 2021, Accepted: 23 March 2021, Published online: 20 December 2021

\begin{abstract}
Intrapreneurship is becoming a key factor in the growth of a company in a highly dynamic and progressively more competitive business environment. The idea of intrapreneurship is to encourage greater employee involvement within the organisation in which they work, giving them the freedom to innovate and experiment in a proactive, creative, and innovative way. In the startups, the role of intrapreneurship is of great relevance knowing that startups are designed to scale and grow exponentially in a short time and with few resources. Innovation is at the core of a startup and intrapreneurship initiatives allow leveraging this capacity in startups. Accordingly, this study seeks to explore the phenomenon of intrapreneurship in startups, seeking to understand how formal and informal intrapreneurship initiatives are taken on by startups, and also exploring the role played by existing resources to support these initiatives. The results of the study allow us to conclude that startups value intrapreneurship initiatives despite financial constraints that overlap with time constraints that affect what can be allocated to these activities. Finally, medium-sized startups and those with more qualified human capital tend to value and support intrapreneur initiatives more intensely. In contrast, startups with less academically qualified human capital offer worse conditions and support to intrapreneur activities.
\end{abstract}

Keywords

human capital, talent management, entrepreneurship, innovation, organisational management

\section{Introduction}

Startups have become the focus of public policies since they present a high potential for growth in the short term, besides being innovative (Gulati and DeSantola, 2016; Spender et al., 2017). Knowing and debating the importance of startups is fundamental to understanding today's forms of work, innovation, and economy. A startup is more than a mere company. It can be seen as a state of mind or a vision, which is supported by its founder and acts to create a business opportunity in an unexplored or unstable market. It does not have a fixed business model but explores the possibilities according to the opportunities (Salamzadeh and Kawamorita Kesim, 2015).

There is no consensus on the definition of a startup. However, several characteristics can be observed in startups. One of the generally agreed characteristics is that a startup is a company in its initial phase of activity. Besides this being the stage in the life of an organisation, Gundolf et al. (2017) argue that what defines a startup is innovation in the construction of its products and services. Fiorentino et al. (2021) combine these two visions by indicating that a startup is an innovative company in its initial phase and with great growth potential. The startup concept also includes the component of the business model which, according to Slávik (2019) should be innovative, repeatable, and scalable. In this sense, a startup finds new and creative solutions to solve a problem or need and can grow quickly without proportionally increasing expenses. Since a startup operates with a limited amount of resources in a scenario of great uncertainty, it is necessary to develop a product or service that can reach a large number of customers and generate profit quickly.

Delivering an innovative product or service is the main goal of a startup (Colombelli et al., 2016). Accordingly, initiatives that only seek to improve production processes or internal procedures are not framed in the concept of a startup. Another characteristic of startups is that they operate in environments of extreme uncertainty. Consequently, the response of the public when using the product or service is not known. Therefore, if there is no doubt in the execution process, and all the elements are known a priori, 
the company cannot be considered a startup. According to Burton et al. (2019), immaturity is not only visible in the processes but also in the whole organisation.

Besides presenting new concepts and solutions in the market, one of the main roles of startups is to challenge existing models and to incorporate technology and innovation in products and services that improve people's lives. Therefore, and as Gavet (2020) states, the starting point of the startups should be the creation of innovative and technological solutions to problems and demands that still have no answers. A paradigm shift is thus a requirement for these companies, which is generally seen as a challenge for large companies already established in the market. This shift is also accompanied by a change of mentality in the operating model of start-ups These companies anchor their operations in processes based on agility, little fear of making mistakes, many proofs of concept, strong collaboration capabilities and strong presence of technology (Berg et al., 2020; Lopez Hernandez et al., 2018; Klotz et al., 2014).

It becomes evident that innovation belongs to the essence of a startup. Startups are designed to scale and grow exponentially in a short period of time and with little resources. According to Keir (2019), these companies offer a completely different learning curve from a traditional company, allowing their employees to undertake new projects within the organisational environment and encouraging employees to promote ideas for new projects through intrapreneurship. However, to foster this kind of culture it is necessary to have a team engaged with this purpose and receptive to taking risks and learning from the daily challenges that are proposed. In this sense, this study seeks to explore this phenomenon by conducting a quantitative empirical study with Portuguese startups and in which it is explored how startups promote intrapreneurship, particularly through the allocation of time and financial resources. This study becomes relevant to understand strategically the role of intrapreneurship in the development and growth of start-ups.

The manuscript is organised as follows. First, the existing literature on the intrapreneurship phenomenon is reviewed and the relevant research questions that guide the development of this study are also defined. Next, the methodology of the study is presented. After that, the results of the study are presented considering the outcomes of the descriptive statistical analysis and ANOVA analysis. After that, the results are discussed, taking into account the relevance and added value provided by this study. Finally, the conclusions are addressed, the limitations of the study are explored and suggestions for future work are indicated.

\section{Literature review}

Several authors like Nakara et al. (2020), Olugbola (2017), and Tiago et al. (2015) have dedicated themselves to the study of entrepreneurship for a better understanding of this phenomenon and to serve as a help to those who are attracted to this innovative path. The study of entrepreneurship has been gaining in intensity in recent years and therefore both people and organisations must adapt to this reality. In the current studies on entrepreneurship various types of entrepreneurship stand out. As Mulgan (2019) notes, entrepreneurship is expressed in multiple facets of human life and not only in entrepreneurial activity. It is present in several areas such as politics, education, architecture, or social service. However, in the context of this study, we focus on the role of intrapreneurship as a way to promote innovation and the development of new companies.

The concept of intrapreneurship represents the entrepreneurial initiatives that are promoted by the collaborator within an organisation, at any time and anywhere in the company (Antoncic and Hisrich, 2003). Intrapreneurship is related to the individual who works in an organisation and manifests all his/her creativity and initiative to generate innovative products, services, and organisational processes. This is intended to arouse the interest of the organisation in the search for better results and quality services, generating positive results and increasing the competitiveness of the organisation. Neessen et al. (2019) stress that the intrapreneur takes on the role of stimulating the creation of ideas within an organisation. This type of employees with a high entrepreneurial capacity are highly sought after by companies (Selig and Baltes, 2017; Tseng and Tseng, 2019). Nowadays, companies are embedded in an unpredictable and fast-changing scenario, which requires employees with a high capacity for innovation.

However, the idea is not only to have employees with the ability to innovate, but also to open the concept of innovation to promote collaboration among startups in the creation of new products and services. As Chesbrough (2019) states, in the context of open innovation, organisations promote open ideas, thoughts, processes and research to improve their product development, provide better services to their customers, increase efficiency, and enhance added value. Open innovation arises as the result of combining internal and external ideas, as well as internal and external paths to one's market to advance the development of new technologies in products and processes (Lopez-Vega et al., 2016). The involvement of open innovation can foster in startups the development of internal competencies leveraging collaboration with other players. 
The knowledge necessary for the intrapreneur activity resides in people. It is these individuals who identify problems and create solutions for them, aiming at gains for the organisation. Amo (2010) mentions that in intrapreneurs workers identify imperfections that emerge from the unbalanced distribution of information and develop actions to identify opportunities in these imperfections that can be exploited. Learning should be an inherent part of the business. Abbas et al. (2020) recommend that to gain the maximum advantage over organisational learning there must be processes for knowledge and idea management that are open, accessible to all and often used and reviewed so that learning can be disseminated throughout the organisation. Several approaches and platforms for the management of ideas and knowledge emerge within organisations and these allow employees to participate in innovation processes, giving a voice and power to the company's employees (Almeida et al., 2019; Raunio et al., 2018).

The intrapreneur's activity is carried out in accordance with the organisation's objectives, in which the environment and resources can facilitate or hinder this action. The intrapreneur environment is born and expands according to the culture of the organisations. Menzel et al. (2007) point out that an organisation's power structure and hierarchical webs can suffocate the freedom of collaborators, minimising their capacity to innovate. These inhibiting factors are also reported by Yildirım et al. (2019) when highlighting the role of emotional intelligence and creativity in the entrepreneurial process. However, organisations also emerge that have the audacity to maintain flexible organisational structures, in which the creative capacity of their employees has been decisive for their development through cost reduction and increased quality (Jena and Memon, 2018). Nowadays, the intrapreneur is one of the most important resources possessed by highly competitive companies and the challenge is to increase the number of employees with these characteristics. According to Vargas-Halabí et al. (2017) intrapreneurship should be raised through the commitment of managers, encouraging teamwork, stimulating open discussion, and the existence of a risk-free environment. Ibidunni et al. (2016) add the role of talent as a component of the entrepreneurial process and with impact in the organisational performance. Therefore, developing and retaining talent emerge as relevant factors. Moghaddas et al. (2020) also add that organisational empowerment is a relevant factor for intrapreneurship. It becomes important to realise that intrapreneurship is fostered within the startups since their more flexible and flat hierarchical structure will tend to facilitate the emergence of intrapreneurship initiatives. Consequently, two research questions have been established that seek to understand how intrapreneurship is promoted in the context of startups:

- RQ1: Startups tend to promote intrapreneur activities in an opportunistic manner.

- RQ2: The promotion of intrapreneurship is an integral part of the startup strategy.

The intrapreneur is in constant competitive activity in organisations, always taking risks, putting into practice the capacity for innovation. Blanka (2019) points out that the intrapreneur is in constant observation in his workplace, always looking for improvements, and is always uncomfortable with the current situation. In this sense, the intrapreneur seeks to become more and more capable to overcome the challenges presented to him/her. For this to happen, Camelo-Ordaz et al. (2012) state that the individual must be audacious and very creative. Through creative ideas, it becomes possible to take advantage of opportunities, see solutions in problems and convert them into a business. Therefore, the more the entrepreneur develops his creativity, the greater potential he/she will have to deal with the adversities that arise along the way.

Intrapreneurs are the employees who have the ability to realise their ideas and turn them into action. To achieve this, they must strongly align their personal goals with the professionals. These individuals also stand out for their capacity for leadership and innovation focused on results (Moriano et al., 2014). They also have communication and persuasion skills with a global vision of the organisation (Alam et al., 2020). From this conception, the conclusion emerges that an individual to develop as an intra-entrepreneur must present characteristics in his/her personality that are compatible with that of the entrepreneur profile.

The activity of the intrapreneur is conditioned by the context in which his or her activity takes place. As Neessen et al. (2019) point out, the intra-entrepreneur does not have all the freedom to develop his ideas and projects because he/she needs to respect the rules and norms of the organisation. However, this factor does not prevent his or her entrepreneurial actions from being recognised by top management when they are aligned with the mission, goals, and objectives of the organisation. Therefore, the employee who transcends the specific responsibilities of his position and performs tasks on his own initiative, and has a vision of the company's future, is exercising intrapreneurship. 
Intrapreneurship often arises more from the individual actions of employees than from previously established processes. This finding has led to the classification that intrapreneurship can be formal or informal. In the formal dimension, Karimi et al. (2011) point out that organisations try to facilitate the emergence of entrepreneurs and their initiatives in various ways. These companies are supposed to promote a pleasant working environment, seek to eliminate or else minimise the barriers that hinder entrepreneurial initiatives, and maintain a broad and open structure of communication. Promoting business transparency is also a key element in intrapreneurship processes (Zakutniaia and Hayriyan, 2017). Therefore, it should be clear what the business strategy is, and where the focus is for the growth and development of new products. In this sense, innovation emerges as a key factor in the future of the business. Furthermore, rewards associated with entrepreneurial activity can also be established (de VilliersScheepers, 2011). On the other hand, in the case of informal intrapreneurship, entrepreneurship emerges in organisations that do not favour the establishment of a favourable climate for innovation. In these situations, the intrapreneur will need to have a high level of perseverance to overcome bureaucratic obstacles and get their ideas and proposals accepted by the organisation (Reuther et al., 2018). A climate favourable to innovation in startups - as recognised in the studies by Choi et al. (2020) and Gundolf et al. (2017) can be complemented with other policies, namely through the allocation of time and financial resources for innovation activity. Accordingly, the following research questions have been established:

- RQ3: Intrapreneurship is promoted by startups through the allocation of time for this purpose.

- RQ4: Intrapreneurship is promoted by startups through the allocation of financial resources for this purpose.

Finally, the startups present several heterogeneous characteristics and whose impact on the perception of intrapreneur activity becomes relevant to know. In the first place, and as was made explicit in the absence of a consensual definition of a startup, the dimension of these organisations is not a differentiating factor. In this sense, startups can be either micro companies, small companies, medium-sized enterprises, or large enterprises. Likewise, the number of years of activity of startups can also be quite heterogeneous. In line with this, it is relevant to explore how the intrapreneurship phenomenon is exploited by these organisations. Finally, Gaskell (2019), Jebali and
Meschitti (2021) state that human capital is a fundamental element in the development of startup activities. Academic qualifications emerge as a factor to be explored in the intrapreneurship dynamics promoted in the startups. Overall, three research questions were established:

- RQ5: The startup dimension is a determining factor in the intrapreneurship policies promoted by startups.

- RQ6: The number of years of activity is a determining factor in the intrapreneurship policies promoted by startups.

- RQ7: The academic qualifications of employees are a determining factor in the intrapreneurship policies promoted by startups.

\section{Methodology}

This study employs a quantitative methodology to analyse the phenomenon of intrapreneurship in the context of startups. According to Anderson et al. (2016), the quantitative research methodology aims to explain through a systemic investigation of observable phenomena through data collection, analysed using methods based on mathematical, statistical, or computational techniques. Quantitative research involves the collection and analysis of quantifiable data. Aidley (2019) stresses that measurement is essential because it allows empirical observation and its connection with the conceptual dimension of research. In this approach, all quantitative data are numerical data and allow the application of a diverse set of techniques (e.g., descriptive statistics, multivariate statistics, correlational statistics, etc.) obtained through research, questionnaires or by manipulation of pre-existing statistical data.

An analysis of variance (ANOVA) was adopted to assess the impact of control variables (i.e., dimension, number of years of activity, and academic qualification of employees) on intrapreneurship policies promoted by startups. This procedure is used to compare the distribution of three or more groups in independent samples. The analysis of variance is also a way to summarise a linear regression model in which using the F test it is possible to test the hypothesis that any source of variation in the model is equal to zero. The basic difference between the hypothesis tests and the ANOVA is the number of samples. While in the hypothesis tests one works with two samples, the ANOVA compares the average of more than two samples and determines if at least one differs significantly from the others.

A survey was designed to collect data through crosssectional research. The survey was distributed by email between $15^{\text {th }}$ May 2020 and $30^{\text {th }}$ October 2020 to Portuguese 
startups incubated in science parks in Portugal and the autonomous islands of Azores and Madeira. A total of 315 valid responses were obtained. A response is considered valid if all control variables have been filled in and at least $50 \%$ of the questionnaire is filled in. Table 1 shows the distribution of the sample data. The data were explored using the SPSS v.21 software. Most startups (almost 60\%) are micro companies followed by small companies. The number of large enterprises is very small which does not allow its correct statistical treatment using ANOVA. Most companies have less than 3 years of activity. However, the number of startups with more years of activity is also significant to allow a statistical analysis using ANOVA. However, the same is not true for the academic qualifications of employees, as only 5 startups report that most of their employees are not graduates. Most employees (62.5\%) are graduates, followed by companies in which individuals with $\mathrm{PhDs}$ represent most of their employees.

Four dimensions of intrapreneurship have been incorporated into the survey and intend to address the first four research questions, respectively:

1. intrapreneurship is promoted in an opportunistic way;

2. fostering intrapreneurship is part of the startup strategy;

3. intrapreneurship is promoted by startup through the allocation of time for this purpose; and

4. intrapreneurship is promoted by startup through the allocation of financial resources for this purpose.

Table 1 Sample data distribution

\begin{tabular}{|c|c|c|}
\hline Variable & $\begin{array}{l}\text { Absolute } \\
\text { value }\end{array}$ & $\begin{array}{l}\text { Relative } \\
\text { value }\end{array}$ \\
\hline \multicolumn{3}{|l|}{ Dimension } \\
\hline Micro company (less than 10 employees) & 188 & 0.593 \\
\hline Small company (10 to 49 employees) & 101 & 0.319 \\
\hline $\begin{array}{l}\text { Medium-sized enterprise ( } 50 \text { to } 249 \\
\text { employees) }\end{array}$ & 26 & 0.082 \\
\hline Large enterprise ( 250 or more employees) & 2 & 0.006 \\
\hline \multicolumn{3}{|l|}{ Number of years of activity } \\
\hline Less than 3 years & 131 & 0.413 \\
\hline Between 3 and 5 years & 87 & 0.274 \\
\hline Between 5 and 10 years & 66 & 0.208 \\
\hline More than 10 years & 33 & 0.104 \\
\hline \multicolumn{3}{|l|}{ Academic qualifications of employees } \\
\hline Most employees are not graduated & 5 & 0.016 \\
\hline $\begin{array}{l}\text { The number of graduated and non-graduated } \\
\text { are similar }\end{array}$ & 45 & 0.142 \\
\hline Most employees are graduated & 198 & 0.625 \\
\hline Most of the employees have a PhD & 69 & 0.218 \\
\hline
\end{tabular}

A total of 21 questions were included in the questionnaire that explore the startups' strategy regarding talent attraction, talent development, talent retention, intrapreneurship, innovation, and internationalisation. A Likert scale consisting of 5 levels as proposed by McLeod (2019) has been adopted (i.e., strongly disagree, disagree, neither agree not disagree, agree, and strongly agree). The Likert scale has been used in several scientific studies in the management and innovation fields. Unlike the dichotomous scale (i.e., yes/no), the Likert scale allows for measuring attitudes and knowing the interviewee's degree of compliance with the proposed statements. In this sense, the response categories serve to capture the intensity of the respondents' perception.

\section{Results}

\subsection{Descriptive analysis}

Table 2 presents the statistical analysis of the dimensions explored in the survey. The data reveals that most startups promote intrapreneurship in their business strategy although it is also promoted opportunistically. Both approaches tend to coexist. Regarding the allocation of time and financial resources for this activity the data collected are less enlightening. The allocation of time tends to be privileged over the allocation of financial resources. The last two dimensions regarding intrapreneurship practices present a larger standard deviation which means a greater dispersion of responses. In this sense we can observe that there is considerable dispersion in the allocation of time and financial resources for intrapreneurship activities in Portuguese startups. It is revealed that the adoption of these practices is still quite asymmetric.

The boxplot of the variables under analysis was also drawn as shown in Fig. 1. A boxplot is a graphical tool that allows visualisation of the distribution and outliers of the data, thus providing a complementary means to develop

Table 2 Sample data distribution

\begin{tabular}{lllll}
\hline Variable & Mean & Median & Mode & $\begin{array}{c}\text { Std. } \\
\text { dev. }\end{array}$ \\
\hline $\begin{array}{l}\text { Intrapreneurship is promoted in } \\
\text { an opportunistic way (v1) }\end{array}$ & 3.850 & 4 & 4 & 1.0205 \\
$\begin{array}{l}\text { Fostering intrapreneurship is } \\
\text { part of the startup strategy (v2) }\end{array}$ & 3.799 & 4 & 4 & 0.9796 \\
$\begin{array}{l}\text { Intrapreneurship is promoted } \\
\text { by startup through the } \\
\text { allocation of time for this } \\
\text { purpose (v3) }\end{array}$ & 3.516 & 4 & 4 & 1.1835 \\
$\begin{array}{l}\text { Intrapreneurship is promoted } \\
\text { by startup through the } \\
\text { allocation of financial resources } \\
\text { for this purpose (v4) }\end{array}$ & 3.137 & 3 & & \\
\hline
\end{tabular}




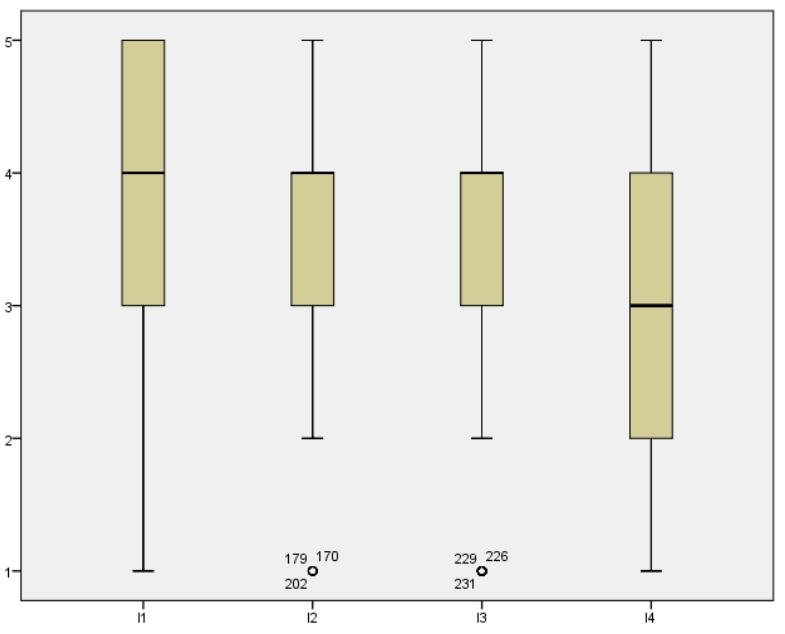

Fig. 1 Boxplot representation

a perspective on the distribution of data. Descriptive statistics such as minimum, maximum, first quartile, median and third quartile form the boxplot. The data reveal that outliers appear in v2 and v3. In fact, the behaviour of v3 and $\mathrm{v} 4$ is very similar. This reveals that the startups that strategically foment intrapreneurship are also those that allocate time to this activity. However, they do not always necessarily allocate resources to this activity. Graphically it is visible that there is relative symmetry in v4. Finally, $\mathrm{v} 1$ has a negative asymmetry with a higher concentration of values in the upper part of the boxplot, with the third quartile corresponding to the maximum.

\subsection{ANOVA analysis}

Table 3 presents the ANOVA analysis considering the size of the company dimension. A significance level of 5\% $(\alpha=0.05)$ was adopted in this process. Significant differences arise for medium-sized companies. For the four variables (from v1 to v4) the perception of the importance of intrapreneurship and the way this class of startups exploits this phenomenon is different from what is seen with the other classes of startups (i.e., micro companies and small ones). The size of the startups therefore presents itself as a discriminating factor in the implementation of intrapreneurship. Larger startups are those with a higher propensity for intrapreneurship activities and have greater ability to allocate resources (i.e., time and financial).

Table 4 shows the results of the ANOVA analysis for the number of years of activity dimension. Overall, the number of years of startup activity is not a discriminating factor in the analysis of the intrapreneur phenomenon. Only significant differences arise for the variables regarding time and financial resources allocated to intrapreneurship for startups between 5 and 10 years of activity.
Finally, Table 5 presents the results of ANOVA analysis for the academic qualifications of employees' dimension. Significant differences arise in this dimension, which are in two different poles. Startups with a similar number of graduated and non-graduated employees present a lower perception for intrapreneurship in all variables. However, this behaviour is the opposite for startups in which most of their employees have a PhD. In the latter case, these startups are more receptive and promote intrapreneurship in all variables under study.

\section{Discussion}

Intrapreneurship is a modality of entrepreneurship that does not have as a fundamental objective to establish a new organisation, but to create or develop an innovative solution that contributes to the development of the activities of an existing company. As Rivera (2017) points out, developing innovative solutions related to the organisation of the entrepreneur is essential to ensure that the business is not obsolete, and that new approaches and products are used to generate value for the business. Innovation is

Table 3 ANOVA analysis of the company's size

\begin{tabular}{lcccccc}
\hline Variable & \multicolumn{2}{c}{ Micro company } & \multicolumn{2}{c}{ Small company } & \multicolumn{2}{c}{$\begin{array}{c}\text { Medium-sized } \\
\text { enterprise }\end{array}$} \\
\hline & Mean & Sig. & Mean & Sig. & Mean & Sig. \\
V1 & 3.798 & 0.501 & 3.800 & 0.613 & 4.480 & $<1 * 10^{-3}$ \\
V2 & 3.733 & 0.369 & 3.782 & 0.857 & 4.360 & 0.002 \\
V3 & 3.431 & 0.333 & 3.510 & 0.961 & 4.160 & $<1 * 10^{-3}$ \\
V4 & 3.005 & 0.137 & 3.228 & 0.452 & 3.720 & 0.002 \\
\hline
\end{tabular}

Table 4 ANOVA analysis the number of years of activity

\begin{tabular}{|c|c|c|c|c|c|c|c|c|}
\hline \multirow{2}{*}{$\frac{\frac{0}{\pi}}{\frac{\pi}{\Xi}}$} & \multicolumn{2}{|c|}{$\begin{array}{c}\text { Less than } 3 \\
\text { years }\end{array}$} & \multicolumn{2}{|c|}{$\begin{array}{l}\text { Between } 3 \\
\text { and } 5 \text { years }\end{array}$} & \multicolumn{2}{|c|}{$\begin{array}{l}\text { Between } 5 \\
\text { and } 10 \text { years }\end{array}$} & \multicolumn{2}{|c|}{$\begin{array}{c}\text { More than } 10 \\
\text { years }\end{array}$} \\
\hline & Mean & Sig. & Mean & Sig. & Mean & Sig. & Mean & Sig. \\
\hline V1 & 3.855 & 0.957 & 3.741 & 0.341 & 3.938 & 0.470 & 3.939 & 0.556 \\
\hline $\mathrm{V} 2$ & 3.771 & 0.755 & 3.779 & 0.840 & 3.969 & 0.147 & 3.636 & 0.383 \\
\hline V3 & 3.405 & 0.319 & 3.477 & 0.760 & 3.785 & 0.044 & 3.531 & 0.931 \\
\hline V4 & 2.992 & 0.201 & 3.140 & 0.985 & 3.415 & 0.035 & 3.152 & 0.934 \\
\hline
\end{tabular}

Table 5 ANOVA analysis of the academic qualifications of employees

\begin{tabular}{lcccccc}
\hline Variable & $\begin{array}{c}\text { Number similar } \\
\text { of graduated and } \\
\text { non-graduated } \\
\text { employees }\end{array}$ & \multicolumn{2}{c}{$\begin{array}{c}\text { Most } \\
\text { employees are } \\
\text { graduated }\end{array}$} & $\begin{array}{c}\text { Most of the } \\
\text { employees have } \\
\text { a PhD }\end{array}$ \\
\hline V1 & 3.295 & 0.001 & 3.791 & 0.410 & 4.406 & $<1^{*} 10^{-3}$ \\
V2 & 3.159 & $<1 * 10^{-3}$ & 3.802 & 0.966 & 4.279 & $<1^{*} 10^{-3}$ \\
V3 & 2.477 & $<1 * 10^{-3}$ & 3.543 & 0.736 & 4.162 & $<1^{*} 10^{-3}$ \\
V4 & 2.000 & $<1 * 10^{-3}$ & 3.194 & 0.488 & 3.750 & $<1^{*} 10^{-3}$ \\
\hline
\end{tabular}


in the essence of a startup that is designed to scale and grow exponentially in a short time and with few resources. Furthermore, startups offer a learning curve completely different from a traditional company, offering a favourable environment for its employees to undertake within the organisational environment (Petch, 2016). The promotion of intrapreneurship in startups is promoted simultaneously in two different but complementary ways. From one perspective, the survey data shows that startups regularly encourage the development of intrapreneurship projects by their employees. This type of projects often arises at the initiative of the collaborators themselves according to a bottom-up approach to intrapreneurship. Therefore, in RQ1 it can be observed that startups tend to promote intrapreneur activities in an opportunistic way. In another perspective, the top-down initiatives of intrapreneurship are also relevant. Startups have also indicated that most of them promote intrapreneurship in their organisational strategy as explored in RQ2.

The forms of incentive to intrapreneur activity are not fully established in startups. The allocation of time for intrapreneur activity as explored in RQ3 is considered in about $70 \%$ of the startups surveyed. However, in other startups, there are difficulties in allocating time for this activity due to the liquidity difficulties of these companies in the short term and market demands. As stated by Moodie (2015), startups are environments of great instability and in which employees are required to make a strong commitment in the first years of activity. In this sense, there is little time available for these activities. This difficulty is increased when we look at the allocation of financial resources as explored in RQ4. In this dimension, there is a great asymmetry with a great divergence of approaches by the startups. In statistical terms, it has been possible to conclude that there are difficulties in allocating financial resources to these initiatives. Startups offer characteristics such as management support, organisational structure, and autonomy that are relevant to intrapreneur activity. However, as Ñeessen et al. (2019) point out, it is also important to provide financial resources for this activity that are not generally available in startups, particularly in the smaller ones.

This study also explored the role of several control variables in the promotion of intrapreneurship in startups. The size of the startup is a determining factor in understanding intrapreneur practices in startups as established in RQ5. Medium-sized startups are those in which intrapreneurship is most encouraged by the organisational initiative of these companies, but also by the involvement of their employees. This result is aligned with the work done by Gomes et al. (2009), in which it is explored the impact of company's size on innovative performance and evidenced that larger companies can have the innovation management process and greater resources for intrapreneurship activity. Therefore, and as expected, the time and financial resources allocated to entrepreneurial activity are also greater in medium-sized startups.

The number of years of startup activity as defined in RQ6 is a factor that does not prove discriminating in the role of intrapreneurship. However, a different situation applies to the qualification of employees, which shows that in RQ7 the academic qualifications of employees are a determining factor in the policies of intrapreneurship promoted by start-ups. The role of qualification has been essentially addressed in scientific studies looking at the perspective of the founders (Alfalih, 2019; Marvel et al., 2016; Ratzinger et al., 2018). However, the distinction between collaborators and founders of a startup is not always clear. In fact, especially in micro startups, the founders are also employees. The qualification of these individuals emerges as a relevant factor to understand the practices of intrapreneurship in startups. Startups with lower employee qualifications have less solid intrapreneurship practices and less support these initiatives through the allocation of time and financial resources. On the other hand, intrapreneurship practices are more valued in companies where most employees have a PhD. As van Wetten et al. (2020) point out, intrapreneur skills are relevant in the innovation activity of products, services and processes, hence greater academic competence is relevant in the execution of these activities. These skills tend to be more valued in individuals with higher academic qualifications.

\section{Conclusion}

Intrapreneurship is promoted by startups using both formal and informal approaches. Most of the startups included in this study reveal that fostering entrepreneurship is part of the startup strategy. Moreover, employees are also responsible for opportunistically promoting intrapreneurship practices. The organisational structure of the startups reveals itself as an important factor for these initiatives to be welcomed by the founders. However, there are also constraints associated with the allocation of time and resources that make these initiatives not a priority for all startups. In fact, the lack of financial resources to support intrapreneurship initiatives is a more critical limiting element than the lack of time allocation for these activities. 
The size of the startups is a factor that contributes to understanding the intrapreneurship phenomenon. Medium-sized startups tend to encourage intrapreneurship practices more than micro and small-sized startups. It is also the case that in this class of startups more financial and time resources are allocated to these activities. The academic qualification of employees is also another dimension where it was possible to identify distinct behaviours of startups. Startups with a similar number of graduated and non-graduated employees have greater difficulties in developing intrapreneurship activities, while startups with a higher qualification of their human capital encourage the emergence of intrapreneurship initiatives and in addition, offer financial and time conditions for the development of these activities.

This study offers both theoretical and practical contributions. In the theoretical component, this study is relevant by studying the intrapreneurship phenomenon among startups. It also explores how the characteristics of the startups (i.e., size, years of activity, qualification of employees) influence the intrapreneurship activities promoted

\section{References}

Abbas, J., Zhang, Q., Hussain, I., Akram, S., Afaq, A., Shad, M. A. (2020) "Sustainable Innovation in Small Medium Enterprises: The Impact of Knowledge Management on Organizational Innovation through a Mediation Analysis by Using SEM Approach", Sustainability, 12(6), Article number: 2407. https://doi.org/10.3390/su12062407

Aidley, D. (2019) "Introducing Quantitative Methods: A Practical Guide", Bloomsbury Publishing London, UK.

Alam, M. Z., Kousar, S., Shabbir, A., Kaleem, M. A. (2020) "Personality traits and intrapreneurial behaviour: Moderated role of knowledge sharing behaviour in diverse group of employees in developing country", Asia Pacific Journal of Innovation and Entrepreneurship, 14(1), pp. 31-46.

https://doi.org/10.1108/APJIE-09-2019-0068

Alfalih, A. A. (2019) "Investigating critical resource determinants of start-ups: An empirical study of the MENA region", Cogent Economics \& Finance, 7(1), Article number: 1628494. https://doi.org/10.1080/23322039.2019.1628494

Almeida, F., Kennedy, A. J., Lin, B., Nowak, I. V. (2019) "Measuring innovation through a crowd source initiative", International Journal of Innovation Science, 11(3), pp. 471-488.

https://doi.org/10.1108/IJIS-04-2019-0046

Amo, B. W. (2010) "Corporate entrepreneurship and intrapreneurship related to innovation behaviour among employees", International Journal of Entrepreneurial Venturing, 2(2), pp. 144-158. https://doi.org/10.1504/IJEV.2010.034819

Anderson, D. R., Sweeney, D. J., Williams, T. A., Camm, J. D., Cochran, J. J. (2016) "Quantitative Methods for Business", Cengage Learning, Boston, MA, USA. by the startups. In the practical dimension, the results of this study are important for these companies to realise the importance of intrapreneurship as a fundamental factor for the promotion of innovation and greater competitiveness of these companies in the market. Furthermore, the study also offers contributions to the establishment of supportive public policies that encourage intrapreneurship in startups. This study contains some limitations that it is relevant to mention. Only Portuguese startups were included so it is relevant to consider the replication of this study for other geographical areas in the future. No information was collected on the sector of activity of the startups either. Therefore, and as future work, it would be important to realise how the sector of activity of the startups has an impact on the intrapreneur activities developed by these companies. Finally, this study explores only the role of intrapreneurship in the development and growth processes of startups. The role of intrapreneurship in the initial stages of conception and establishment of a startup, which are mainly promoted by the founders but are essential in the processes of market entry, is not addressed.

Antoncic, B., Hisrich, R. D. (2003) "Clarifying the intrapreneurship concept", Journal of Small Business and Enterprise Development, 10(1), pp. 7-24. https://doi.org/10.1108/14626000310461187

Berg, V., Birkeland, J., Nguyen-Duc, A., Pappas, I. O., Jaccheri, L. (2020) "Achieving agility and quality in product development - an empirical study of hardware startups", Journal of Systems and Software, 167, Article number: 110599. https://doi.org/10.1016/j.jss.2020.110599

Blanka, C. (2019) "An individual-level perspective on intrapreneurship: a review and ways forward", Review of Managerial Science, 13(5), pp. 919-961.

https://doi.org/10.1007/s11846-018-0277-0

Burton, M. D., Colombo, M. G., Rossi-Lamastra, C., Wasserman, N. (2019) "The organizational design of entrepreneurial ventures", Strategic Entrepreneurship Journal, 13(3) Special Issue: Organizational Design of Entrepreneurial Ventures, pp. 243-255.

https://doi.org/10.1002/sej.1332

Camelo-Ordaz, C., Fernández-Alles, M., Ruiz-Navarro, J., Sousa-Ginel, E. (2012) "The intrapreneur and innovation in creative firms", International Small Business Journal: Researching Entrepreneurship, 30(5), pp. 513-535.

https://doi.org/10.1177/0266242610385396

Chesbrough, H. (2019) "Open Innovation Results: Going Beyond the Hype and Getting Down to Business", Oxford University Press, Oxford, UK.

https://doi.org/10.1093/oso/9780198841906.001.0001 
Choi, D. S., Sung, C. S., Park, J. Y. (2020) "How Does Technology Startups Increase Innovative Performance? The Study of Technology Startups on Innovation Focusing on Employment Change in Korea", Sustainability, 12(2), Article number: 551. https://doi.org/10.3390/su12020551

Colombelli, A., Krafft, J., Vivarelli, M. (2016) "To be born is not enough: the key role of innovative start-ups", Small Business Economics, 47(2), pp. 277-291. https://doi.org/10.1007/s11187-016-9716-y

de Villiers-Scheepers, M. J. (2011) "Motivating Intrapreneurs: The Relevance of Rewards", Industry and Higher Education, 25(4), pp. 249-263. https://doi.org/10.5367/ihe.2011.0051

Fiorentino, R., Longobardi, S., Scaletti, A. (2021) "The early growth of start-ups: innovation matters. Evidence from Italy", European Journal of Innovation Management, 24(5), pp. 1525-1546. https://doi.org/10.1108/EJIM-02-2020-0057

Gaskell, A. (2019) "Why Human Capital is the Key to Startup Success", Forbes [online] Available at: https://www.forbes.com/sites/adigaskel1/2019/05/01/why-human-capital-is-the-key-to-startup-success/?sh $=5551 \mathrm{f} 758105 \mathrm{~b}$ [Accessed: 12 November 2020]

Gavet, M. (2020) "Trampled by Unicorns: Big Tech's Empathy Problem and How to Fix It", Wiley, Hoboken, NJ, USA.

Gomes, C. M., Kruglianskas, I., Scherer, F. L. (2009) "Company Size Effect in Innovative Performance", Journal of Technology Management \& Innovation, 4(4), pp. 13-31. https://doi.org/10.4067/S0718-27242009000400002

Gulati, R., DeSantola, A. (2016) "Start-ups That Last", Harvard Business Review, March 2016, pp. 54-61. [online] Available at: https://hbr. org/2016/03/start-ups-that-last [Accessed: 21 December 2020]

Gundolf, K., Gast, J., Géraudel, M. (2017) "Startups' Innovation Behaviour: An Investigation Into The Role Of Entrepreneurial Motivations", International Journal of Innovation Management, 21(7), Article number: 1750054

https://doi.org/10.1142/S1363919617500542

Ibidunni, S., Osibanjo, O., Adeniji, A., Salau, O. P., Falola, H. (2016) "Talent Retention and Organizational Performance: A Competitive Positioning in Nigerian Banking Sector", Periodica Polytechnica Social and Management Sciences, 24(1), pp. 1-13. https://doi.org/10.3311/PPso.7958

Jebali, D., Meschitti, V. (2021) "HRM as a catalyst for innovation in start-ups", Employee Relations, 43(2), pp. 555-570. https://doi.org/10.1108/ER-03-2020-0140

Jena, L. K., Memon, N. Z. (2018) "Does Workplace Flexibility Usher Innovation? A Moderated Mediation Model on the Enablers of Innovative Workplace Behavior", Global Journal of Flexible Systems Management, 19(1), pp. 5-17. https://doi.org/10.1007/s40171-017-0170-8

Karimi, A., Malekmohamadi, I., Ahmadpour D.aryani, M., Rezvanfar, A. (2011) "A conceptual model of intrapreneurship in the Iranian agricultural extension organization: Implications for HRD", Journal of European Industrial Training, 35(7), pp. 632-657. https://doi.org/10.1108/03090591111160779

Keir, M. Y. A. (2019) "Prospective on Human Resources Management in Startups", Information Sciences Letters, 8(3), pp. 81-88. https://doi.org/10.18576/is1/080301
Klotz, A. C., Hmieleski, K. M., Bradley, B. H., Busenitz, L. W. (2014) "New Venture Teams: A Review of the Literature and Roadmap for Future Research", Journal of Management, 40(1), pp. 226-255. https://doi.org/10.1177/0149206313493325

Lopez Hernandez, A. K., Fernandez-Mesa, A., Edwards-Schachter, M. (2018) "Team collaboration capabilities as a factor in startup success", Journal of Technology Management \& Innovation, 13(4), pp. $13-23$. https://doi.org/10.4067/S0718-27242018000400013

Lopez-Vega, H., Tell, F., Vanhaverbeke, W. (2016) "Where and how to search? Search paths in open innovation", Research Policy, 45(1), pp. $125-136$ https://doi.org/10.1016/j.respol.2015.08.003

Marvel, M. R., Davis, J. L., Sproul, C. R. (2016) "Human Capital and Entrepreneurship Research: A Critical Review and Future Directions", Entrepreneurship: Theory and Practice, 40(3), pp. 599-626.

https://doi.org/10.1111/etap.12136

McLeod, S. (2019) "Likert Scale Definition, Examples and Analysis", Simply Psychology [online] Available at: https://www.simplypsychology.org/likert-scale.html [Accessed: 12 December 2020]

Menzel, H. C., Aaltio, I., Ulijn, J. M. (2007) "On the way to creativity: Engineers as intrapreneurs in organizations", Technovation, 27(12), pp. 732-743. https://doi.org/10.1016/j.technovation.2007.05.004

Moghaddas, S. Z., Tajafari, M., Nowkarizi, M. (2020) "Organizational empowerment: A vital step toward intrapreneurship", Journal of Librarianship and Information Science, 52(2), pp. 529-540. https://doi.org/10.1177/0961000619841658

Moodie, A. (2015) "For some startup employees, less time spent at work is more", The Guardian [online] Available at: https://www.theguardian. com/sustainable-business/2015/apr/15/startups-work-life-balanceshorter-hours-productivity [Accessed: 12 December 2020]

Moriano, J. A., Molero, F., Topa, G., Lévy Mangin, J.-P. (2014) "The influence of transformational leadership and organizational identification on intrapreneurship", International Entrepreneurship and Management Journal, 10(1), pp. 103-119. https://doi.org/10.1007/s11365-011-0196-x

Mulgan, G. (2019) "Social Innovation: How Societies Find the Power to Change", Bristol University Press, Bristol, UK https://doi.org/10.2307/j.ctvs89dd3

Nakara, W. A., Laouiti, R., Chavez, R., Gharbi, S. (2020) "An economic view of entrepreneurial intention", International Journal of Entrepreneurial Behavior \& Research, 26(8), pp. 1807-1826. https://doi.org/10.1108/IJEBR-12-2019-0693

Ñeessen, P. C. M., Caniëls, M. C. J., Vos, B., de Jong, J. P. (2019) "The intrapreneurial employee: toward an integrated model of intrapreneurship and research agenda", International Entrepreneurship and Management Journal, 15(1), pp. 545-571. https://doi.org/10.1007/s11365-018-0552-1

Olugbola, S. A. (2017) "Exploring entrepreneurial readiness of youth and startup success components: Entrepreneurship training as a moderator", Journal of Innovation \& Knowledge, 2(3), pp. 155-171. https://doi.org/10.1016/j.jik.2016.12.004 
Petch, N. (2016) "What's It Like Working For A Startup", Entrepreneur Europe, [online] 02 May 2016. Available at: https://www.entrepreneur.com/article/274974 [Accessed: 27 December 2020].

Ratzinger, D., Amess, K., Greenman, A., Mosev, S. (2018) "The impact of digital start-up founders' higher education on reaching equity investment milestones", The Journal of Technology Transfer, 43(3), pp. 760-778.

https://doi.org/10.1007/s10961-017-9627-3

Raunio, M., Nordling, N., Kautonen, M., (2018) "Open Innovation Platforms as a Knowledge Triangle Policy Tool-Evidence from Finland", Foresight and STI Governance, 12(2), pp. 62-76. https://doi.org/10.17323/2500-2597.2018.2.62.76

Reuther, K., Borodzicz, E. P., Schumann, C.-A. (2018) "Identifying Barriers to Intrapreneurship", In: IEEE International Conference on Engineering, Technology and Innovation (ICE/ITMC), Stuttgart, Germany, pp. 1-9. https://doi.org/10.1109/ICE.2018.8436373

Rivera, M. J. (2017) "Leveraging innovation and intrapreneurship as a source for organizational growth", International Journal of Innovation Science, 9(2), pp. 137-152. https://doi.org/10.1108/IJIS-12-2016-0057

Salamzadeh, A., Kawamorita Kesim, H. (2015) "Startup Companies: Life Cycle and Challenges", In: 4th International Conference on Employment, Education and Entrepreneurship, Belgrade, Serbia, pp. 1-11. https://doi.org/10.2139/ssrn.2628861

Selig, C. J., Baltes, G. H. (2017) "Clarifying the roles in corporate entrepreneurship", In: International Conference on Engineering, Technology and Innovation (ICE/ITMC), Madeira, Portugal, pp. 879-887. https://doi.org/10.1109/ICE.2017.8279976

Slávik, S. (2019) "The Business Model of Start-Up - Structure and Consequences", Administrative Sciences, 9(3), Article number: 69. https://doi.org/10.3390/admsci9030069
Spender, J-C., Corvello, V., Grimaldi, M., Rippa, P. (2017) "Startups and open innovation: a review of the literature", European Journal of Innovation Management, 20(1), pp. 4-30.

https://doi.org/10.1108/EJIM-12-2015-0131

Tiago, T., Faria, S., Couto, J. P., Taigo, F. (2015) "Fostering Innovation by Promoting Entrepreneurship: From Education to Intention", Procedia - Social and Behavioral Sciences, 175, pp. 154-161. https://doi.org/10.1016/j.sbspro.2015.01.1186

Tseng, C., Tseng, C. C. (2019) "Corporate entrepreneurship as a strategic approach for internal innovation performance", Asia Pacific Journal of Innovation and Entrepreneurship, 13(1), pp. 108-120. https://doi.org/10.1108/APJIE-08-2018-0047

van Wetten, S. J. L., Gerards, R., de Grip, A. (2020) "Are graduates' intrapreneurial skills optimally used for innovation?", Technovation, 96-97, Article number: 102131.

https://doi.org/10.1016/j.technovation.2020.102131

Vargas-Halabí, T., Mora-Esquivel, R., Siles, B. (2017) "Intrapreneurial competencies: development and validation of a measurement scale", European Journal of Management and Business Economics, 26(1), pp. 86-111. https://doi.org/10.1108/EJMBE-07-2017-006

Yıldırım, F., Trout, I. Y., Hartzell, S. (2019) "How Are Entrepreneurial Intentions Affected by Emotional Intelligence and Creativity?", Periodica Polytechnica Social and Management Sciences, 27(1), pp. 59-65. https://doi.org/10.3311/PPso. 12619

Zakutniaia, A., Hayriyan, A. (2017) "Transparency as competitive advantage of innovation driven companies", Business Ethics and Leadership, 1(1), pp. 46-54. https://doi.org/10.21272/bel.2017.1-06 